\title{
Relationship of fire behavior to tallgrass prairie herbage production
}

\author{
TERRENCE G. BIDWELL AND DAVID M. ENGLE
}

\begin{abstract}
Authors are associate professor and professor, Division of Agricultural Sciences and Natural Resources, Oklahoma State University, Stillwater, Okla.
\end{abstract}

\begin{abstract}
Little evidence has been found to relate fire intensity to herbaceous vegetation response. Our objective was to determine if components of post-fire herbaceous standing crop in a tallgrass prairie could be related to either fire behavior variables or to timetemperature relationships. We used canonical correlation to relate standard fire behavior variables (fireline intensity, rate of spread, and heat per unit area) and time-temperature relationships (degree seconds at 3 vertical strata) to post-fire components of the herbaceous stending crop of tallgrass prairie. Spring headfires and backfires were applied to $10 \times 20$-m plots on a moderately grazed, shallow prairie range site in good to excellent range condition. The first canonical correlation of the 3 fire behavior variables and the standing crop variables generally indicated a strong relationship between the 2 sets of variates. The canonical correlation between the degree seconds and standing crop sets of variates was slightly less than the canonical correlation between the fire behavior parameters and standing crop. Neither the fire behavior canonical variate nor the degree second canonical variate was strongly related to any single component of the June or August standing crop, but this study demonstrates that fire behavior is a factor affecting community herbaceous vegetation response to fire in tallgrass prairie.
\end{abstract}

Key Words: canonical correlation, fire effects, fire intensity, Great Plains, Oklahoma, true prairie

Relating fire behavior to vegetation response in forests and shrublands has received considerable research attention (Byram 1959, Alexander 1982), but research of this nature has been limited on fires in grassland communities (Roberts et al. 1988). Fireline intensity and other measurements of fire behavior related to the combustion process are used in forest fire ecology and fire behavior studies and have been suggested for relating vegetation responses in other wildland ecosystems (Alexander 1982, Albini 1984). However, little evidence has been found to relate fire intensity to herbaceous vegetation response (Armour et al. 1984, Roberts et al. 1988). If this is true, prescriptions can be written to achieve a high intensity fire for scorching the crowns of woody plants and to accomplish other objectives requiring an intense fire without concern for negative effects on herbaceous vegetation.

Temperature and time-temperature relationships have been used to explain the response of herbaceous vegetation and plants to fire (Stinson and Wright 1969, Wright 1971, Hobbs and Gimingham 1984, Engle et al. 1989). Fire temperature is difficult to interpret because it is not a measure of heat flux (Alexander 1982). However, if time-temperature relationships can be related to herbaceous vegetation response when standard measures of fire behavior can not, then it is likely that time-temperature relation-

This is journal article 5522 of the Oklahoma Agricultural Experiment Station. Manuscript accepted 6 Feb. 1992. ships can substitute as an index of the flow of heat from the combustion process. This index may then be useful for relating herbaceous vegetation response to fire. Our objective was to determine if components of post-fire herbaceous vegetation standing crop in a tallgrass prairie are related to either standard fire behavior variables or to time-temperature relationships.

\section{Study Area}

Our study area is located at the Oklahoma State University Research Range approximately $15 \mathrm{~km}$ west southwest of Stillwater, Okla. Mean annual precipitation is $81 \mathrm{~cm}$ (Meyers 1982). The study area is on a shallow prairie range site in the Central Rolling Red Prairies Land Resource Area (USDA Soil Conservation Service 1981). The soil is a Grainola clay loam with a clay B horizon (fine, mixed thermic Vertic Haplustalf). Dominant grasses include big bluestem (Andropogon gerardii Vitman), switchgrass (Panicum virgatum L.), indiangrass [Sorghastrum nutans (L.) Nash], and little bluestem [Schizachyrium scoparium (Michx.) Nash]. The study area was grazed at a moderate to heavy stocking rate (2.4 $\mathrm{AUM} \mathrm{ha}^{-1}$ ) from mid-July to mid-November in 1985 and 1986 before the treatments were applied in the spring of 1986 and 1987.

\section{Methods and Materials}

Fire behavior and standing crop responses were measured on 10 $\times 20$-m plots. Eight plots were burned in 1986 and 8 plots were burned in 1987. Plots were located on almost level land $(<2 \%$ slope) and were oriented southeast to northwest to correspond to the southeast winds which prevail during the spring. Eight plots were burned with headfires and 8 were burned with backfires. Plots were burned in March and April as growth of $\mathrm{C}_{4}$ grasses was beginning, as recommended by Launchbaugh and Owensby (1978). Plots were burned with line headfires and backfires ignited with a drip torch at plot borders.

Weather and fuel were sampled immediately before each fire (Table 1). Fuel load was measured by clipping herbaceous vegetation in 5 quadrats $(0.5 \times 0.5 \mathrm{~m})$ per plot immediately before each

Table 1. Weather and fuel conditions present immediately before the fires in tallgrass prairie.

\begin{tabular}{lrrrr}
\hline \hline Variable & Min & Max & Mean & SE \\
\hline Relative humidity (\%) & 18 & 51 & 34 & 2 \\
Ambient air temp. ( $\left.{ }^{\circ} \mathrm{C}\right)$ & 15 & 26 & 21 & 1 \\
Wind speed km hr $^{-1}$ ) & 3 & 24 & 10 & 1 \\
Fuel load dry (kg ha ${ }^{-1}$ ) & 2,370 & 5,580 & 3,570 & 260 \\
Fuel moisture (standing) (\%) & 5 & 59 & 28 & 4 \\
Fuel moisture (fallen) (\%) & 13 & 148 & 48 & 9 \\
Fuel moisture (total) (\%) & 12 & 60 & 31 & 4 \\
Fuel load CV (\%)! & 15 & 70 & 37 & 15 \\
\hline
\end{tabular}

Coefficient of variation within a burn plot. 
Table 2. Fire behavior and degree sounds variables used in canonical variates to relate to herbage production in tallgrass prairie in north central Oklahoma, 1986 and 1987.

\begin{tabular}{|c|c|c|c|c|c|}
\hline Variable & Code & Min & $\operatorname{Max}$ & Mean & SE \\
\hline \multicolumn{6}{|l|}{ Fire behavior } \\
\hline $\begin{array}{l}\text { Fireline intensity }\left(\mathrm{kW} \mathrm{m}^{-1}\right) \\
\text { Rate of spread }\left(\mathrm{m} \mathrm{min}^{-1}\right) \\
\text { Heat per unit area }\left(\mathrm{kJ} \mathrm{m}^{2}\right)\end{array}$ & $\begin{array}{l}\text { BFI } \\
\text { ROS } \\
\text { HA }\end{array}$ & $\begin{array}{r}31 \\
1 \\
3,619\end{array}$ & $\begin{array}{r}2,778 \\
35 \\
8,593\end{array}$ & $\begin{array}{r}543 \\
6 \\
5,750\end{array}$ & $\begin{array}{r}235 \\
3 \\
12\end{array}$ \\
\hline \multicolumn{6}{|l|}{ Degree seconds } \\
\hline $\begin{array}{l}\text { Degree seconds } 0 \mathrm{~cm}\left({ }^{\circ} \mathrm{CXS}\right) \\
\text { Degree seconds } 30 \mathrm{~cm}\left({ }^{\circ} \mathrm{C} \times \mathrm{S}\right) \\
\text { Degree seconds } 60 \mathrm{~cm}\left({ }^{\circ} \mathrm{C} \times S\right)\end{array}$ & $\begin{array}{l}\text { DS0 } \\
\text { DS30 } \\
\text { DS60 }\end{array}$ & $\begin{array}{r}110 \\
207 \\
63\end{array}$ & $\begin{array}{l}44,765 \\
26,851 \\
10,183\end{array}$ & $\begin{array}{r}10,711 \\
8,511 \\
4,446 \\
\end{array}$ & $\begin{array}{r}1,870 \\
925 \\
464\end{array}$ \\
\hline
\end{tabular}

fire. Clipped herbage was separated into standing and fallen (litter and mulch) and weighed immediately in the field. Fuel moisture, expressed on a dry weight basis, was determined after samples were oven dried at $70^{\circ} \mathrm{C}$ for 72 hours. Weather variables measured using a belt weather kit included ambient air temperature, relative humidity, and wind speed at $2 \mathrm{~m}$ above the soil surface.

Standard parameters of fire behavior used as independent variables included rate of spread, Byram's fireline intensity (Byram 1959), and heat per unit area (Table 2). Byram's fireline intensity is the product of the fuel low heat of combustion $\left(\mathrm{kJ} \mathrm{kg}^{-1}\right)$, the weight of the fuel consumed per unit area $\left(\mathrm{kg} \mathrm{m}^{-2}\right)$, and rate of spread (m $\mathrm{s}^{-1}$ ). Low heat of combustion was determined by bomb calorimetry for the total fuel sample (standing and fallen). Rate of spread was measured with a stopwatch and photographically in a manner similar to that of Britton et al. (1977). Heat vield was determined by bomb calorimetry for the total fuel sample (standing and fallen). Heat per unit area $\left(\mathrm{kJ} / \mathrm{m}^{2}\right)$ is 60 times the quotient of Byram's fireline intensity and rate of spread (Rothermel and Deeming 1980). Because of mid-fire changes in wind direction, rate of spread was not measured on 4 plots. This resulted in Byram's fireline intensity and heat per unit area estimates on 12 (5 headfires and 7 backfires) rather than 16 plots.

Time-temperature relationships were determined from fire temperatures measured at 2-second intervals using high-temperature, chromel-alumel thermocouples at 3 stations per plot and at 3 heights relative to the soil surface $(0 \mathrm{~cm}=$ soil surface; $30 \mathrm{~cm}=$ top of herbaceous canopy; $60 \mathrm{~cm}=$ above the herbaceous canopy). The thermocouple wire was 24 AWG with thermojunctions approximately 6-mm long and $1-\mathrm{mm}$ in diameter and with 5- to 7-m leads overbraided with high temperature ceramic fiber insulation. An electronic data logger (Campbell Scientific model 21X with multiplexer) with tape data storage was used to record time-temperature data. Traces of time-temperature that were recorded for each thermocouple allowed estimates of degree sounds above ambient temperature as described by Potter et al. (1983). Several other parameters are also available from these fire temperature traces, including the maximum fire temperatures and residence time (Rothermel and Deeming 1980). Of these, we chose to relate degree sounds to vegetation response because degree seconds has been suggested to relate to fire intensity (Albini 1976, Trollope 1984) and to fire effects on herbaceous plants (Wright 1971). A program in Turbo Pascal for IBM compatible microcomputers was used to generate the time-temperature parameter from the thermocouple data. A discrete summation algorithm was used to arrive at an estimate of degree sounds, which is the area above ambient temperature and under the time-temperature curve (Engle et al. 1989).

Herbage standing crop was measured the year following the burn by clipping five $0.5 \times 0.5-\mathrm{m}$ quadrats per plot in early July and August as previously reported by Bidwell et al. (1990). Clipped samples were separated by hand into 5 categories: (1) tallgrasses including big bluestem, indiangrass, and switchgrass; (2) little bluestem; (3) other perennial grasses and grass-like plants, primarily tall dropseed (Sporobolus asper (Michx.) Kunth.), silver bluestem (Bothriochloa saccharoides (Sw.) Rydb.), scribner panicum (Panicum oligosanthes Schultes), fall witchgrass (Leptoloma cognatum) Schult.), rattail grass (Manisuris cylindrica (Michx.) Ktze.), sedges (Cyperus spp.), (Carex spp.), rushes (Juncus); (4) forbs, primarily common broomweed (Xanthocephalum dracunculoides (DC.) Shinners), trailing ratany (Krameria secundiflora DC.)., western ragweed (Ambrosia psilostachya DC.), yarrow (Achillea lanulosa Nutt.), purple prairie clover (Petalostemum purpureum (Vent.) Rydberg), scurfpea (Psoralea simplex (Nutt.) T. \& G.), wild indigo (Baptisia australis (L.) R., Br.); and (5) total herbaceous standing crop. We selected these 5 vegetation categories because of their relative importance as forage and cover sources for both cattle and wildlife, or because of their expected response to fire.

We expected burning date to have an effect on the relative responses of these categories as demonstrated in Kansas tallgrass prairie (Towne and Owensby 1984), but no category of standing crop differed $(P>0.05)$ with respect to burning date (Bidwell et al. 1990). Therefore, we assumed fire effects to be a function of fire behavior, and we did not use burning date as a variable in the analysis. Other independent variables, including fire type (Bidwell et al. 1990), weather conditions, fuel loading, variation in fuel loading, fuel moisture, and burn year, were also not included in the analysis. Although these variables significantly affected vegetation response as determined by multiple regression analysis (SAS Institute Inc. 1988), including them was not germane to the study objectives of relating fire behavior and time-temperature relationships to herbaceous vegetation production.

The relationships between herbaceous production the growing season following burning (Table 3 ) and fire behavior and time-

Table 3. Standing crop of tallgrass prairie vegetation the growing season following spring fire in north central Oklahoma, 1986 and 1987.

\begin{tabular}{lccrr}
\hline \hline Variable & Min & Max & Mean & SE \\
\hline & $\ldots \ldots$ & $\ldots-(\mathrm{kg} / \mathrm{ha})$ & $\ldots$ & $\ldots$ \\
Tallgrasses, June & 260 & 1,020 & 640 & 50 \\
Tallgrasses, August & 880 & 2,570 & 1,690 & 130 \\
Little bluestem, June & 150 & 740 & 370 & 50 \\
Little bluestem, August & 300 & 1,620 & 760 & 90 \\
Other grasses, June & 700 & 1,620 & 1,090 & 60 \\
Other grasses, August & 1,580 & 3,960 & 2,280 & 150 \\
Forbs, June & 140 & 730 & 320 & 40 \\
Forbs, August & 150 & 580 & 320 & 30 \\
Total standing crop, June & 1,700 & 3,580 & 2,530 & 140 \\
Total standing crop, August & 4,170 & 6,890 & 5,100 & 190 \\
\hline
\end{tabular}


Table 4. Standardized canonical coefficients for the first canonical correlation between fire behavior variables and standing crop, and the canonical correlation'.

\begin{tabular}{|c|c|c|c|c|c|c|c|c|}
\hline \multicolumn{2}{|c|}{ Fire behavior variables } & \multicolumn{5}{|c|}{ Standing crop variables } & \multirow{2}{*}{$\begin{array}{c}\text { Canonical } \\
\text { correlation }\end{array}$} & \multirow[b]{2}{*}{$\mathbf{P}>\mathbf{F}^{2}$} \\
\hline$\widehat{\mathrm{ROS}}$ & HA & TG & LB & OG & Forbs & Total & & \\
\hline $\begin{array}{cc}\text { June standing crop } \\
-2.8956 & 2.2441\end{array}$ & -1.0119 & 0.1793 & 0.6190 & -0.5626 & 0.2609 & 0.7647 & 0.88 & 0.75 \\
\hline $\begin{array}{cc}\text { August standing crop } \\
-5.4609 & 4.8306\end{array}$ & -0.6438 & -4.5447 & -1.6093 & -6.3127 & -0.4380 & 8.4112 & 0.93 & 0.07 \\
\hline
\end{tabular}

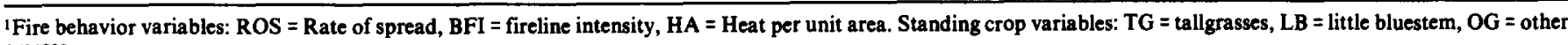
grasses.

2Significance of the canonical correlations according to the likelihood ratio test.

temperature relationships were analyzed by canonical correlation (SAS Institute Inc. 1988). Canonical correlation analysis is a procedure that can be used for simultaneously analyzing a mixture of species variables and environmental variables (Ludwig and Reynolds 1988). This is a multivariate procedure that uses linear canonical equations with multiple dependent and independent variables in contrast to multiple linear regression that uses multiple independent variables. The procedure finds a linear combination from each set of variables, such that the correlation between each set is maximized. The procedure then finds a second set of canonical variables, uncorrelated with the first pair, that produces the second highest correlation coefficient. The process continues until the number of pairs of canonical variables equals the number of variables in the smaller group of original variables (SAS Institute Inc. 1988).

The results of the first canonical correlation are presented. Additional canonical correlations added little interpretive power. Correlations between the canonical variables and the original variables are presented to aid in interpreting these relationships. Plots of the 2 sets of canonical variables of the first canonical correlation were used to aid in interpreting the canonical correlations and the correlation coefficients (Johnson and Wichern 1988:455). Selected original variable sets (i.e., components of the standing crop and degree seconds variables) were regressed to illustrate the relationships suggested by the canonical correlation.

\section{Results and Discussion}

\section{Fire Behavior}

Armour et al. (1984) and Roberts et al. (1988) found little evidence that fire intensity affects herbaceous vegetation, but we found a strong relationship between fire behavior and components of herbaceous vegetation standing crop in this tallgrass prairie. The first canonical correlation indicates a strong relationship between the 2 sets of canonical variates composed of the standard fire behavior variables and the standing crop variables although the canonical correlation for the June data is not significantly different from zero (Table 4). The canonical coefficients for the fire behavior variables differ somewhat in relative size between the June and August standing crop models, but the signs of the coefficients are consistent. In general, the fire behavior variables correlated well with all the canonical variates, except for the heat per unit area variable, which was poorly correlated with the variate pairs for the August standing crop (Table 5).

The first pair of canonical variates for the June and August standing crop data indicate a close relationship between the fire behavior and standing crop variates (Fig. 1). We interpret the fire behavior variate as representing overall fire intensity in which fire intensity decreases with increasing values of the variate. The fire with the lowest fire behavior and standing crop set of variate coordinates had the greatest fireline intensity, $2,778 \mathrm{~kW} \mathrm{~m}^{-1}$. The standing crop variate generally increased as the fire behavior variate increased numerically (i.e., decreased in intensity) (Fig. 1). The relationship between August standing crop and fire behavior appears to be best explained by the variation in little bluestem standing crop.

August little bluestem standing crop was most highly correlated with the fire behavior variate (0.62) (Table 5). A scatter plot (not shown) revealed that August little bluestem standing crop increases as fire behavior decreases (i.e., increasing values of the fire behavior variate). August little bluestem is also best correlated with the canonical variates for August standing crop (0.66) (Table 5). In nearby tallgrass prairies, little bluestem was reduced by high intensity late-summer fires, but total standing crop was not reduced (Ewing and Engle 1988).

\section{Degree Seconds}

Scatterplots of the first pair of canonical variates for the June and August standing crop data indicate a relationship exists between the 2 sets of variables (Fig. 2). Noticeable in the scatterplots is the absence of the outlier observation that occurred in the fire behavior models. The canonical correlations are about as high

Table 5. Correlations between the original fire behavior variables and standing crop variables and the canonical variates of the first canonical correlation.1

\begin{tabular}{|c|c|c|c|c|}
\hline & \multicolumn{2}{|c|}{ Canonical variates for June } & \multicolumn{2}{|c|}{ Canonical variates for August } \\
\hline & Fire behavior & Standing crop & Fire behavior & Standing crop \\
\hline $\begin{array}{l}\text { Fire behavior vari } \\
\text { ROS } \\
\text { BFI } \\
\text { HA }\end{array}$ & $\begin{array}{r}-0.6586 \\
0.6975 \\
-0.6506\end{array}$ & $\begin{array}{r}-0.5811 \\
-0.6154 \\
-0.5740\end{array}$ & $\begin{array}{r}-0.7089 \\
-0.5808 \\
0.1023\end{array}$ & $\begin{array}{r}-0.6617 \\
-0.5421 \\
0.0955\end{array}$ \\
\hline $\begin{array}{l}\text { Standing crop var } \\
\text { Tallgrasses } \\
\text { Little bluestem } \\
\text { Other grasses } \\
\text { Forbs } \\
\text { Total }\end{array}$ & $\begin{array}{l}0.1256 \\
0.5951 \\
0.1730 \\
0.4025 \\
0.6325\end{array}$ & $\begin{array}{l}0.1423 \\
0.6745 \\
0.1960 \\
0.4561 \\
0.7169\end{array}$ & $\begin{array}{r}0.2264 \\
0.6200 \\
-0.1854 \\
-0.1713 \\
0.2039\end{array}$ & $\begin{array}{r}0.2425 \\
0.6642 \\
-0.1986 \\
-0.1836 \\
0.2184\end{array}$ \\
\hline
\end{tabular}

IVariable names are given in Table 4. 

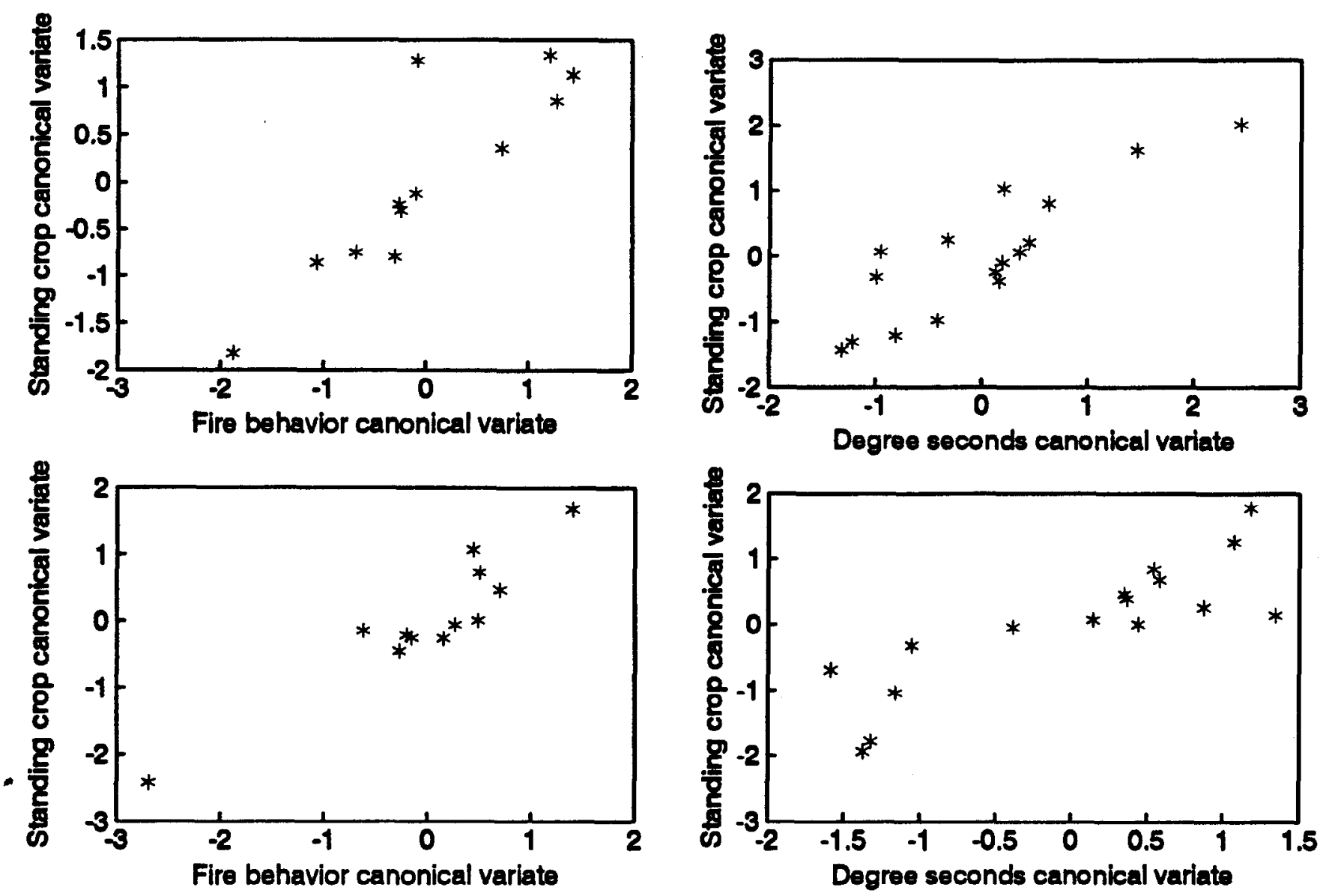

Fig. 1. The first canonical variate of fire behavior plotted against June standing crop (top) and August standing crop (bottom).

between degree seconds and standing crop responses (Table 6) as the canonical correlations between fire behavior and standing crop responses (Table 4).

No thermocouple height was consistently better than another at representing fire temperature effects on herbaceous vegetation. The canonical variate coefficients for the degree seconds variables differed considerably in relative size and sign between the June and August standing crop models (Table 6). Furthermore, the degreeseconds variate for June standing crop correlated best with the DS0 variable $(0.96)$, whereas the degree-seconds variate for the August standing crop data correlated best with the DS60 variable (0.99) (Table 7). The June standing crop variate also best correlated with the DSO variate, whereas the August standing crop variate best correlated with the DS60 variate.

Similar to the fire behavior canonical variate, the degree second canonical variate is not highly correlated to any individual compo-

Fig. 2. The first canonical variate of degree seconds plotted against June standing crop (top) and August standing crop (bottom).

nent of the June or August standing crop (Table 7). The positive correlation between the degree seconds variate and the June little bluestem variable (Table 7) may reflect a time-temperature effect on this species. Little bluestem June standing crop responded positively to increasing values of DSO that was offset by a decline in June standing crop of tallgrasses (Fig. 3). The correlations are not high, and having only 1 fire with DS0 over 20,000 limits the strength of the inferences that can be drawn about these relationships. However, we would expect little bluestem to be more intolerant of high levels of heat near the soil surface than tallgrasses because of its caespitose growth form that elevates a high proportion of apical meristems to near or aboveground level. For example, little bluestem standing crop was reduced the next year following a late-summer fire with DS0 of 44,000 , but not following a fire with DS0 of 10,000 (Ewing and Engle 1988).

Towne and Owensby (1984) concluded that little bluestem

Table 6. Standardized canonical coefficients for the first canonical correlation between degree seconds variables and standing crop, and the canonical correlation'.

\begin{tabular}{|c|c|c|c|c|c|c|c|c|c|}
\hline \multicolumn{3}{|c|}{ Degree seconds variables } & \multicolumn{5}{|c|}{ Standing crop variables } & \multirow{2}{*}{$\begin{array}{l}\text { Canonical } \\
\text { correlation }\end{array}$} & \multirow[b]{2}{*}{$\mathbf{P}>\mathbf{F}^{2}$} \\
\hline DSO & DS30 & DS60 & TG & LB & OG & Forbs & Total & & \\
\hline $\begin{array}{c}\text { June standin } \\
1.0813\end{array}$ & $\begin{array}{l}\text { crop } \\
-0.4132\end{array}$ & 0.2989 & -0.5078 & 0.5735 & 0.2881 & -0.4697 & -0.1043 & 0.87 & 0.12 \\
\hline $\begin{array}{l}\text { August stan } \\
-0.1351\end{array}$ & $\begin{array}{l}18 \text { crop } \\
0.1822\end{array}$ & 0.8858 & 4.2962 & 3.0289 & 5.2841 & 1.1809 & -6.2459 & 0.85 & 0.19 \\
\hline
\end{tabular}

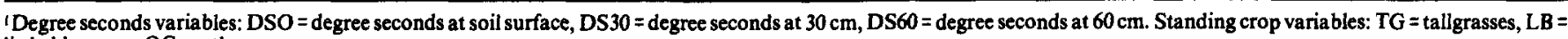
little bluestem, $O G=$ other grasses.

2Significance of the canonical correlations according to the likelihood ratio test. 
Table 7. Correlations between the original degree seconds variables and standing crop variables and the canonical variates of the first canonical correlation.1

\begin{tabular}{|c|c|c|c|c|}
\hline & \multicolumn{2}{|c|}{ Canonical variates for June } & \multicolumn{2}{|c|}{ Canonical variates for August } \\
\hline & Degree seconds & Standing crop & Degree seconds & Standing crop \\
\hline \multicolumn{5}{|c|}{ Degree seconds variables } \\
\hline DSO & 0.9611 & 0.8365 & 0.0772 & 0.0657 \\
\hline DS30 & 0.2289 & 0.1992 & 0.7349 & 0.6249 \\
\hline DS60 & 0.1850 & 0.1610 & 0.9896 & 0.8515 \\
\hline \multicolumn{5}{|c|}{ Standing crop variables } \\
\hline Tallgrasses & -0.5822 & -0.6689 & 0.1114 & 0.1310 \\
\hline Little bluestem & 0.6576 & 0.7556 & 0.0722 & 0.0849 \\
\hline Other grasses & 0.0395 & 0.0454 & 0.5719 & 0.6726 \\
\hline Forbs & -0.3501 & -0.4023 & 0.2176 & 0.2559 \\
\hline Total & -0.2079 & -0.2389 & 0.5005 & 0.5886 \\
\hline
\end{tabular}

IVariable names are given in Table 6.
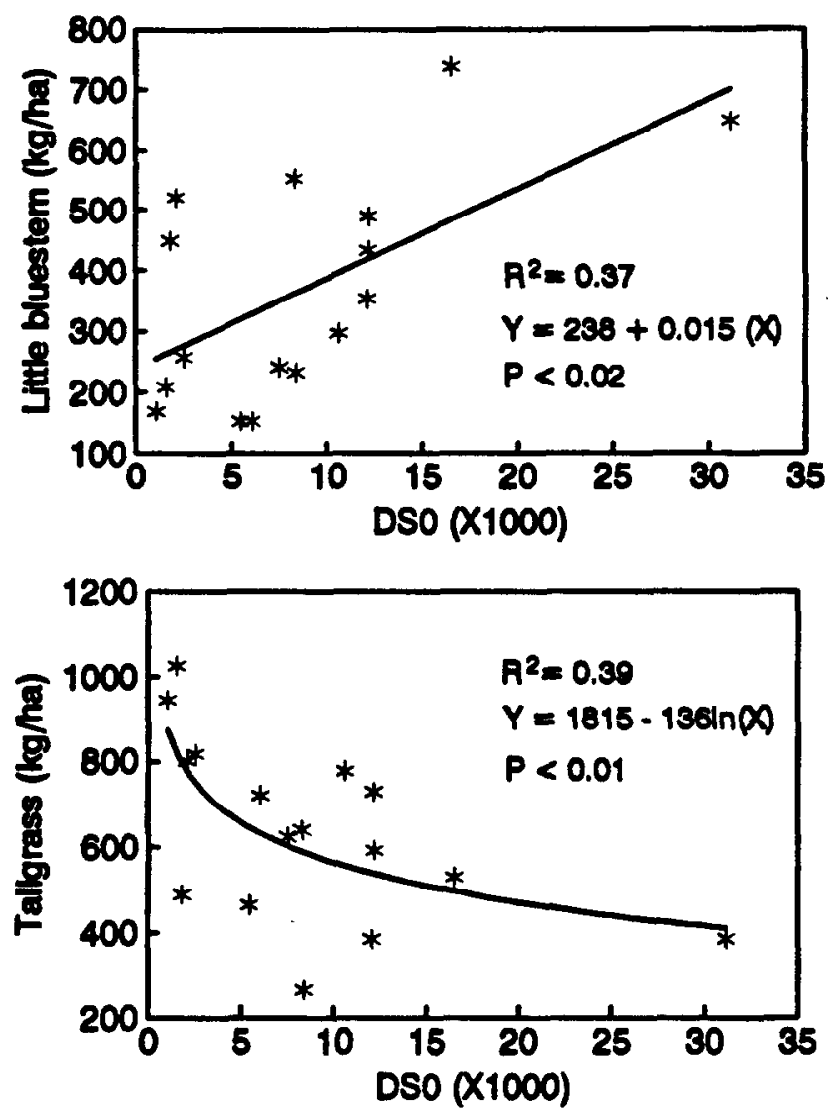

Fig. 3. Degree seconds at the soil surface (DSO) plotted against June standing crop of little bluestem (top) and June standing crop of tallgrasses (bottom).

declines under burning unless conditions are moist because the plant crown is susceptible to fire injury. We interpret the response in the present study as a stimulation in some way by "hotter" fires to produce more relative production of little bluestem in the early growing season, which is accompanied by less relative production of big bluestem in the early growing season. By August the differing responses of the 2 species are no longer present. If this early growing season relationship is valid, then time-temperature relationships may be better suited for relating to this influence than are standard fire behavior variables. More detailed research on the dynamics of seasonal growth patterns of these standing crop components are needed to test this hypothesis. However, our data should be cause for a measure of caution when broadly applying results from fire effects studies based on a single clipping date.

\section{Conclusions}

Season of burn is likely the over-riding factor in standing crop response to burning (Towne and Owensby 1984), but fire type also affects standing crop responses to spring fires (Bidwell et al. 1990). This study demonstrates that fire behavior is related to herbaceous vegetation response in tallgrass prairie. This conflicts with the results of Armour et al. (1984) whose work was in forested vegetation where litter and duff components of the fuel burn independently of each other and have contrasting effects on fire behavior and fire effects. The 2 grasslands studied by Roberts et al. (1988) were each dominated by single species of grass, so a multivariate response would not be expected to result from fires of differing behavior.

Production of herbaceous vegetation in tallgrass prairies, and perhaps in other grasslands with diverse species composition, can be described as a multivariate relationship with fire behavior. Production response is complex and can not be viewed as a univariate response of a single vegetation component responding to a single measured attribute of fire behavior. Neither the fire behavior canonical variate nor the degree seconds canonical variate was highly correlated with any single component of the June or August standing crop, but both sets of variates were generally correlated with overall community response.

Despite the criticism of using temperature as an index to the heat energy released in fires, time-temperature relationships are positively correlated with fire intensity and have been used elsewhere as an index of fire intensity in grassland fires (Trollope 1984). Our results suggest time-temperature relationships could also be useful for relating grassland community production responses to fire.

Generalizations are difficult to make about herbaceous vegetation responses to fire because the fire environment and vegetation are highly variable and they interact, e.g., vegetation production determines fuel load which affects fire behavior. However, it appears that herbaceous vegetation production is related to fire behavior. The exact nature of the relationship and the mechanisms involved in grassland ecosystems deserve further investigation.

\section{Literature Cited}

Albini, F.A. 1976. Estimating wildfire behavior and effects. USDA Forest Serv. Gen. Tech. Rep. INT-30.

Albini, F.A. 1984. Wildland fires. Amer. Scientist 72:590-597.

Alexander, M.E. 1982. Calculating and interpreting forest fire intensities. Can. J. Bot. 60:349-357.

Armour, C.D., S.C. Bunting, and L.F. Neuenschwander. 1984. Fire intensity effects on the understory in ponderosa pine forests. J. Range Manage. 37:44-49. 
Bidwell, T.G., D.M. Engle, and P.L. Claypool. 1990. Effects of spring headfires and backfires on tallgrass prairie. J. Range Manage. 43:211-214.

Britton, C.M., B.L. Karr, and F.A.Sneva. 1977. A technique for measuring rate of fire spread. J. Range Manage. 30:395-397.

Byram, G.M. 1959. Combustion of forest fuels. p. 61-89. In: K.M. Davis (ed.). Forest Fire: Control and Use. McGraw Hill, N.Y.

Engle, D.M., T.G. Bidwell, A.L. Ewing, and J.R. Williams. 1989. A technique for quantifying fire behavior in grassland fire ecology studies. Southwest. Natur. 34:79-84.

Ewing, A.L., and D.M. Engle. 1988. Effects of late summer fire on tallgrass prairie microclimate and community composition. Amer. Midl. Natur. 120:212-223

Johnson, R.A., and D.W. Wichern. 1988. Applied multivariate statistics. Second Ed. Prentice Hall. Englewood Cliffs, N.J.

Hobbs, R.J., and C.H. Gimingham. 1984. Studies on fire on Scottish heathland communities. J. Ecol. 72:223-240.

Launchbaugh, J.L., and C.E. Owensby. 1978. Kansas rangelands: their management based on a half century of research. Kansas Agr. Exp. Sta. Bull. 622., Kansas State Univ., Manhattan.

Ludwig, J.A., and J.F. Reynolds. 1988. Statistical ecology. A primer on methods and computing. John Wiley \& Sons, N.Y.

Meyers, H.R. 1982. Climatological data of Stillwater, Oklahoma 1893-1980. Okla. Agr. Exp. Sta. Res. Rep. P-821.
Potter, R.L., D.N. Ueckert, and J.L. Peterson. 1983. Internal temperature of pricklypear cladophylls during prescribed fire in West Texas. Texas Agr. Exp. Sta., College Station, Tex. PR 4132.

Roberts, F.H., C.M. Britton, D.B. Wester, and R.G. Clark. 1988. Fire effects on tobosograss and weeping lovegrass. J. Range Manage. 41:407-409.

Rothermel, R.C., and J.E. Deeming. 1980. Measuring and interpreting fire behavior for correlation with fire effects. USDA Forest Serv. Gen. Tech. Rep. INT-93.

SAS Institute Inc. 1988. SAS/ STAT user's guide. Release 6.03 Ed. SAS Institute Inc., Cary, N.C. 1028.

Stinson, K.J., and H.A. Wright. 1969. Temperature of headfires in the southern mixed prairie of Texas. J. Range Manage. 24:277-284.

Towne, G., and C. Owensby. 1984. Long-term effects of annual burning at different dates in ungrazed Kansas tallgrass prairie. J. Range Manage. 37:392-397.

Trollope, W.S.W. 1984. Fire behavior. p. 199-217. In: P. de V. Booysen and N.M. Tainton (eds.). Ecological effects of fire in South Africa Ecosystems. Springer-Verlag, N.Y.

USDA Soil Conservation Service. 1981. Land resource regions and major land resource areas of the United States. Agr. Handb. 296, USDA Soil Cons. Serv., Gov. Print. Off., Washington, DC.

Wright, H.A. 1971. Why squirreltail is more tolerant to burning than needle-and-thread. J. Range Manage. 24:277-284.

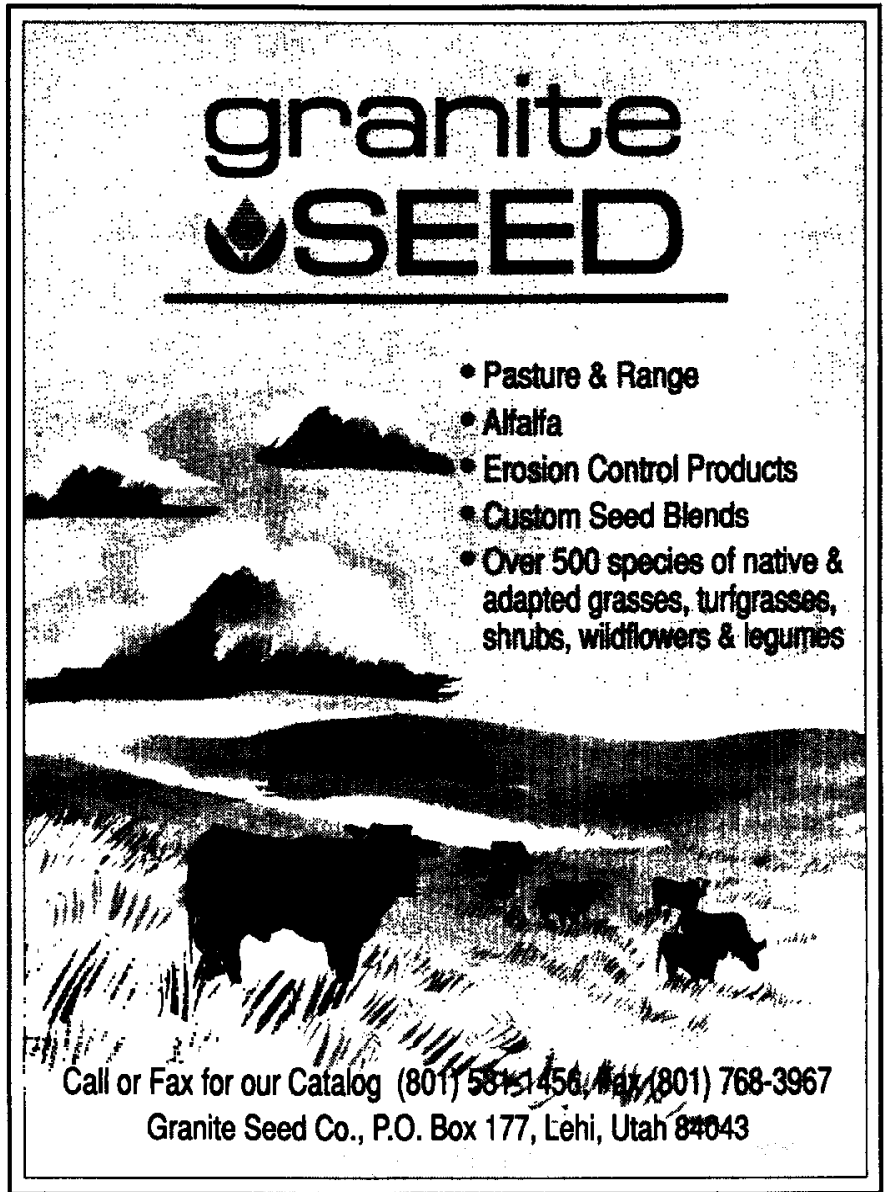

